Jurnal Ekonomi, Bisnis dan Akuntansi (JEBA) Volume 22 No 4 Tahun 2020

\title{
TEORI OF PLANNED BEHAVIOR TERHADAP INTENSI UNTUK MEMBERI INFAQ DAN SHADAQAH MELALUI APLIKASI FINANCIAL TECHNOLOGY (GO-PAY)
}

\author{
Anisa Sains Kharisma ${ }^{1}$, Negina Kencono Putri ${ }^{1}$ \\ ${ }^{1}$ Program Pascasarjana Magister Akuntansi, Fakultas Ekonomi dan Bisnis, Universitas \\ Jenderal Soedirman Purwokerto, Indonesia \\ *Email corresponding author : anisasains08@gmail.com
}

\begin{abstract}
ABSTRAK
Penelitian ini bertujuan untuk mengetahui seberapa besar pengaruh Theory of Planned Behavior (Teori Perilaku Terencana) terhadap niat memberi infaq dan shadaqah dengan menggunakan financial technology (Go-Pay). Data dalam penelitian ini dikumpulkan menggunakan kuesioner dengan sampel penelitian sebanyak 50 Muslim yang menggunakan Go-Pay dan menggunakan accidental sampling. Penelitian ini menggunakan pendekatan kuantitatif dengan analisis regresi linier berganda. Hasil penelitian ini menunjukkan bahwa norma subyektif dan kontrol perilaku yang dipersepsikan berpengaruh signifikan terhadap niat memberi infaq dan shadaqah.
\end{abstract}

Kata kunci: Teori Perilaku Terencana, Infaq, Shadaqah, Teknologi Keuangan

\begin{abstract}
This study aims to determine the influence level of Theory of Planned Behavior toward intention to give infaq and shadaqah using financial technology (Go-Pay). Data in this study collected using questionnaire with sample research of 50 Muslim that using Go-Pay and using accidental sampling. This research uses quantitative approach with multiple linear regression analysis. The result of this study indicate that Subjective norms and perceived behavior control significantly influence the intention to give infaq and shadaqah.

Keywords: Theory of planned behavior, Infaq, Shadaqah, Financial Technology
\end{abstract}

\section{PENDAHULUAN}

Indonesia adalah Negara penganut agama islam terbesar di Dunia yakni sebesar 209,1 juta jiwa atau $87,2 \%$ dari seluruh umat muslim dunia dan menempati urutan pertama dari 10 negara dengan penduduk muslim terbesar di dunia yang diikuti oleh India, Pakistan, Bangladesh, Nigeria, Mesir, Iran, Turki, Algeria dan Maroko (www.dataku.com). Sebagai Negara dengan mayoritas muslim terbesar di Dunia, zakat, infaq dan shadaqah merupakan salah satu sumber pendapatan bagi muslim di Indonesia. Zakat adalah salah satu rukun islam yang sangat penting sehingga selalu disebutkan sejajar dengan shalat (Al- Baqarah : 43) dan salah satu pilar dalam islam yang erat kaitannya dengan ekonomi sehinngga zakat diharapkan dapat membantu perekonomian Indonesia. Selain zakat, masih ada infaq dan shadaqoh yang juga dapat membantu perekonomian Indonesia. Infaq adalah tindakan memberikan sebagian dari harta yang dimiliki kepada orang yang telah diisyaratkan yakni fakir, miskin, yatim piatu dan kerabat lain-lain (Mardany, 2017) sedangkan shadaqah maknanya sama seperti infaq, tetapi shadaqah dapat berupa sesuatu yang tidak material (Nasution, 2015).

Adapun manfaat infaq dan shadaqah secara lebih luas yaitu dengan membayar infaq dan shadaqah akan mendapatkan pahala yang berlipat ganda (Al-Baqarah : 261), semakin dekat dengan Allah (At-taubah : 99), dan sebagai pembuka pintu rezeki serta membersihkan dan menyucikan harta (HR. Tirmidzi). Sedangkan manfaat infaq dan shadaqah bagi penerimanya 
antara lain meringankan beban ekonomi, memungkinkan mereka mengubah keadaan diri mereka dengan modal infaq dan shadaqah yang diterima, mempersempit ruang perbedaan antara si kaya dan si miskin dan dapat menjalin persaudaraan yang erat antara sesama muslim (Zikri, et al, 2017). Begitu pentingnya infaq dan shadaqah bagi kelangsungan hidup umat muslim, sehingga penyaluran infaq dan shadaqah memerlukan perhatian yang khusus.

Permasalahan yang timbul adalah bagaimana cara menyalurkan atau membayar infaq dan shadaqah. Apakah melalui Lembaga penghimpun dan penyalur (BAZNAS, LAZ, Rumah Zakat, Dompet Dhuafa, dll) atau langsung kepada penerima yang bersangkutan. Penelitian Daulay (2014) Menjelaskan bahwa masyarakat enggan menyalurkan zakat infaq dan shadaqah melalui instansi BAZIS / LAZ. Masyarakat lebih memilih memberikan zakat infaq dan shadaqah langsung kepada Mustahik karena pelayanan instansi tersebut yang buruk, selain itu juga Muzakki merasa lebih afdhal jika memberikan zakat infaq dan shadaqahnya langsung kepada Mustahik, terlepas ada atau tidak adanya hubungan keluarga. Kepercayaan terhadap lembaga pengelola zakat terkait informasi dana zakat dan kesadaran untuk membantu Mustahik terdekat juga menjadi alasan Muzakki di Kabupaten Sidoarjo menyalurkan zakat secara langsung (Novianto, 2014). Oleh karena itu, Muzakki memerlukan fasilitas untuk mempermudah dalam menyalurkan dana zakat infaq dan shadaqahnya.

Di era digital sekarang ini, kita dimudahkan oleh teknologi dalam melakukan aktivitas. Salah satunya adalah aktivitas untuk menyalurkan infaq dan shadaqah melalui platform digital payment Go-Pay. Go-Pay adalah salah satu produk Financial Technology (Fintech) dari perusahaan GO-JEK. Financial Technology (Fintech) merupakan gabungan antara jasa keuangan dengan teknologi yang akhirnya mengubah model bisnis dari konvensional menjadi moderat, yang awalnya dalam bertransaksi harus bertatap muka dan membawa sejumlah uang kas, kini dapat melakukan transaksi jarak jauh dan dalam hitungan detik saja. Sedangkan platform digital adalah sebuah program untuk menjalankan sebuah teknologi yakni hardware dan software. Dengan adanya Fintech Go-Pay, diharapkan dapat memudahkan dan meningkatkan minat dalam memberikan infaq dan shadaqah.Penelitian ini bertujuan meneliti seberapa besar niat untuk memberikan infaq dan shadaqah melalui financial technology dengan menggunakan pendekatan theory of planned behavior. Sumber data dalam penelitian ini diperoleh dari kuisioner yang diberikan kepada responden yang aktif menggunakan financial technology, yakni platfrom digital payment Go-Pay. Data yang telah terkumpul kemudian dianalis menggunakan teknik kuantitatif melalui regresi linear berganda.

\section{Infaq}

Infaq berasal dari kata anfaqa yang berarti menghabiskan, membelanjakan, memberi atau menghapus properti. Menurut istilah infaq berarti mengeluarkan sebagian dari harta atau pendapatan atau penghasilan untuk suatu kepentingan yang diperintahkan dalam ajaran Islam. Mardany (2017) mendefinisikan infaq sebagai memberikan sebagian dari harta yang dimiliki kepada orang yang telah diisyaratkan oleh agama untuk memberinya seperti faqir, miskin, yatim piatu, kerabat dan lain-lain. Infaq tidak mengenal nisab atau jumlah harta yang telah ditentukan secara hukum. Secara hukum, infaq terbagi menjadi empat macam (www.kitabisa.com) :1) Infaq mubah, yaitu tindakan mengeluarkan harta untuk perkara mubah seperti berdagang dan bercocok tanam, 2) Infaq wajib, yaitu tindakan mengeluarkan harta untuk perkara wajib seperti mahar (maskawin), menafkahi istri, dan menafkahi istri yang ditalak dalam keadaan iddah, 3) Infaq haram, yaitu tindakan mengeluarkan harta dengan tujuan yang diharamkan Allah, seperti infaqnya orang kafir untuk menghalangi syiar islam (Al-Anfal : 36) dan infaqnya orang islam kepada orang fakir miskin tetapi tidak karena Allah (An-Nisa : 
38), 4) Infaq sunnah, yaitu tindakan mengeluarkan harta dengan niat shadaqah, terbagi menjadi dua kategori berupa infaq untuk jihad dan infaq untuk orang yang membutuhkan

Dalam penelitian ini infaq diberikan oleh pengguna (customer) Go-Pay kepada Driver GoJek ketika customer selesai melakukan pesanan (transportasi, pengiriman barang atau pemesanan makanan). Customer diberi pilihan untuk memberikan atau tidak memberikan infaq atau dalam aplikasi Go-Pay disebut sebagai Tips. Besarnya Tips tersebut berkisar dari Rp1.000,hingga Rp10.000,-. Besarnya infaq tersebut akan langsung masuk ke rekening driver yang bersangkutan, sehingga customer tidak khawatir jika nantinya infaq tidak tersalurkan.

\section{Shadaqah}

Menurut KBBI Shadaqah adalah memberi sesuatu kepada fakir miskin atau kepada yang berhak menerimanya diluar kewajiban zakat dan zakat fitrah sesuai dengan kemampuan pemberi. Secara umum shadaqah adalah mengamalkan harta dijalan Allah dengan ikhlas tanpa mengharapkan imbalan, dan semata-mata mengharapkan ridha-Nya sebagai bukti kebenaran islamnya (Al-Baqarah : 245) dan tidak mengharapkan imbalan jasa atau penggantian (Uyun, 2015). Sedekah dapat berupa hal yang material maupun tidak material. Beberapa macam sedekah yaitu tasbih, tahlil dan tahmid; bekerja dan memberi nafkah kepada keluarga; shadaqah harta (materi).

Dalam penelitian ini, shadaqah diberikan dalam bentuk rating. Setelah Customer selesai melakukan pesanan (transportasi, pengiriman barang atau pemesanan makanan), customer diberikan pilihan untuk memberi rate kepada driver. Rating tersebut berupa bintang, dari satu hingga lima bintang. Semakin bagus pelayanan yang diberikan oleh driver, semakin banyak bintang yang diberikan. Rating tersebut nantinya akan menjadi evaluasi bagi perusahaan Go-Jek untuk meneruskan akan bermitra dengan driver yang bersangkutan atau tidak. Sehingga ketika driver diberi lima bintang, driver akan senang dan itu termasuk shadaqah dalam bentuk nonmaterial.

\section{Attitude}

Sikap merupakan suatu faktor dalam diri seseorang yang dipelajari untuk memberikan respon positif atau negatif pada penilaian terhadap sesuatu yang diberikan. Ajzen (2005) juga menjelaskan bahwa sikap didefinisikan sebagai kecenderungan untuk menanggapi hal-hal yang evaluatif, disukai, atau tidak disukai untuk objek, orang, institusi, atau acara. Osman et al (2015) menegaskan semakin positif sikap individu, maka semakin tinggi pula niat individu untuk melakukan sesuatu. Sikap seorang muslim terhadap suatu perilaku tentu memiliki proses dan prinsipnya sendiri. Proses pengambilan keputusan seorang Muslim dimulai dengan pengantar masalah, yang kemudian diikuti oleh pengambilan informasi, dan evaluasi alternatif. Bagian dari evaluasi alternatif terdiri dari penolakan kemudharatan, persepsi kebutuhan Islam, serta persepsi mardhatillah atau kesenangan Allah SWT, kemudian dari proses ini dapat mengarah pada keputusan untuk melakukan suatu perilaku atau tidak.

Jika seorang muslim memiliki pandangan yang positif terhadap infaq dan shadaqah maka semakin tinggi niat individu muslim tersebut untuk memberikan infaq dan shadaqah. Dalam penelitian ini jika pengguna aplikasi Go-Pay mempunyai pandangan yang positif yakni memberikan infaq dan shodaqah akan membawa manfaat bagi driver yang bersangkutan, maka niat pengguna aplikasi Go-Pay untuk member infaq berupa tips dan shadaqah berupa rating akan semakin tinggi.

\section{Subjective Norms}

Subjective norms merupakan persepsi seseorang tentang pemikiran orang lain yang akan mendukung atau tidak mendukungnya dalam melakukan sesuatu. Subjective norms mengacu pada tekanan sosial yang dihadapi oleh individu untuk melakukan atau tidak melakukan 
sesuatu (Ajzen, 1991). Cruzz et al (2015) menjelaskan bahwa norma subjektif adalah keyakinan individu untuk mematuhi arahan atau saran dari orang disekitarnya (keluarga, teman sebaya dan orang-orang yang dianggap penting ) untuk berpartisipasi dalam melakukan suatu tindakan. Subjective norm adalah hasil dari normative belief yang merupakan hasil dari penerapan kekuatan keyakinan, yaitu pandangan yang relevan tentang suatu perilaku dan motivasi untuk memenui harapan lingkungan sekitar.

Ketika seorang muslim mendapatkan dukungan dari keluarganya, teman sesama muslim dan orang - orang yang dianggap penting untuk berinfaq dan bershadaqah maka akan semakin kuat niat Muslim tersebut untuk memberi infaq dan shadaqah. Jadi, ketika pengguna Go-Pay mendapatkan dukungan dari kelurganya, teman muslim sesame pengguna Go-Pay dan orang lain yang dianggap penting untuk memberikan infaq dan shadaqah kepada driver Go-Jek maka niat untuk memberikan tersebut akan semakin kuat.

\section{Perceived Behavioral Control}

Perceived (persepsi) adalah proses kognitif yang digunakan oleh seseorang untuk menafsirkan dan memahami mengenai suatu hal (Suliyanto, 2015). Perceived behavioral control adalah persepsi kemudahan atau kesulitan dalam melakukan suatu perilaku. Kontrol perilaku merupakan persepi terhadap kekuatan faktor-faktor yang mempermudah atau mempersulit. Ajzen (1991) Perceived behavior control atau kontrol perilaku yang dirasakan sebagai perasaan kemampuan seseorang untuk menunjukkan perilaku yang diinginkan. Kontrol perilaku yang dipersepsikan mengacu pada persepsi orang tentang kemampuan mereka untuk melakukan perilaku tertentu (Osman et al, 2015). Ajzen (1985) menegaskan bahwa dengan behavioral control individu percaya betapa mudah atau sulitnya untuk melakukan perilaku tertentu. Perceived behavioral control dapat secara tidak langsung memengaruhi perilaku, melalui niat sehingga dapat digunakan untuk memprediksi perilaku secara langsung. Niat untuk berperilaku hanya dapat diwujudkan jika perilaku tersebut masih dalam jangkauan kemampuan pribadi. Aktualisasi perilaku dalam kapasitas tertentu masih tergantung pada faktor-faktor non-motivasi seperti ketersediaan peluang dan sumber daya (misalnya waktu, uang, kemampuan, bantuan orang lain).

Seorang muslim yang memiliki sumber daya dan peluang yang baik, harus memanfaatkan kemampuan dan peluang tersebut untuk hal-hal yang baik menurut Islam salah satunya adalah berinfaq dan bershadaqah. Dapat disimpulkan bahwa ketika Muslim pengguna Go-Pay merasa memiliki kemampuan untuk member infaq dan shadaqah kepada driver Go-Jek maka semakin tinggi niat untuk memberikan infaq dan shadaqah tersebut.

\section{Intention}

Fishbein dan Ajzen (2005) menjelaskan intensi sebagai representasi kognitif dan konatif dari kesiapan individu untuk menampilkan suatu perilaku. Intensi merupakan penentu dan disposisi dari perilaku, hingga individu memiliki kesempatan dan waktu yang tepat untuk menampilkan perilaku tersebut secara nyata. Intensi merupakan perantara faktor-faktor motivasional yang memiliki dampak pada perilaku. Secara spesifik, dalam planned behavior theory, dijelaskan bahwa intensi untuk melakukan suatu perilaku adalah indikasi kecenderungan individu untuk melakukan suatu perilaku tersebut. Intensi untuk melakukan suatu perilaku dapat diukur melalui tiga prediktor utama yang memengaruhi intensi tersebut, yaitu behavioral beliefs, normative beliefs, dan control beliefs.

Secara umum, jika individu memiliki intensi untuk melakukan suatu perilaku maka individu cenderung akan melakukan perilaku tersebut; sebaliknya, jika individu tidak memiliki intensi untuk melakukan suatu perilaku maka individu cenderung tidak akan melakukan 
perilaku tersebut. Jadi, jika seorang muslim memiliki intensi untuk memberi infaq atau shadaqah melalui aplikasi Go-Jek maka seorang muslim tersebut cenderung akan memberikan infaq atau shodaqah, dan sebaliknya.

\section{TEKNIK ANALISIS DATA}

Penelitian ini menggunakan data primer berupa kuisioner dan menggunakan teknik accidental sampling dalam pengambilan sample. Penelitian ini menggunakan pendekatan kuantitatif dengan analisis regresi linier berganda. Total Sampel yang digunakan dalam penelitian ini adalah 50 responden. Pengumpulan data dilakukan menggunakan dokumentasi dan kuesioner. Uji kualitas data menggunakan uji validitas dan reliabilitas. Teknik analisis data yang digunakan dalam penelitian ini adalah uji asumsi klasik, multikolinieritas, uji normalitas, uji heterokesdastisitas, linier berganda regresi dan koefisien determinan / R2 (Suliyanto, 2011).

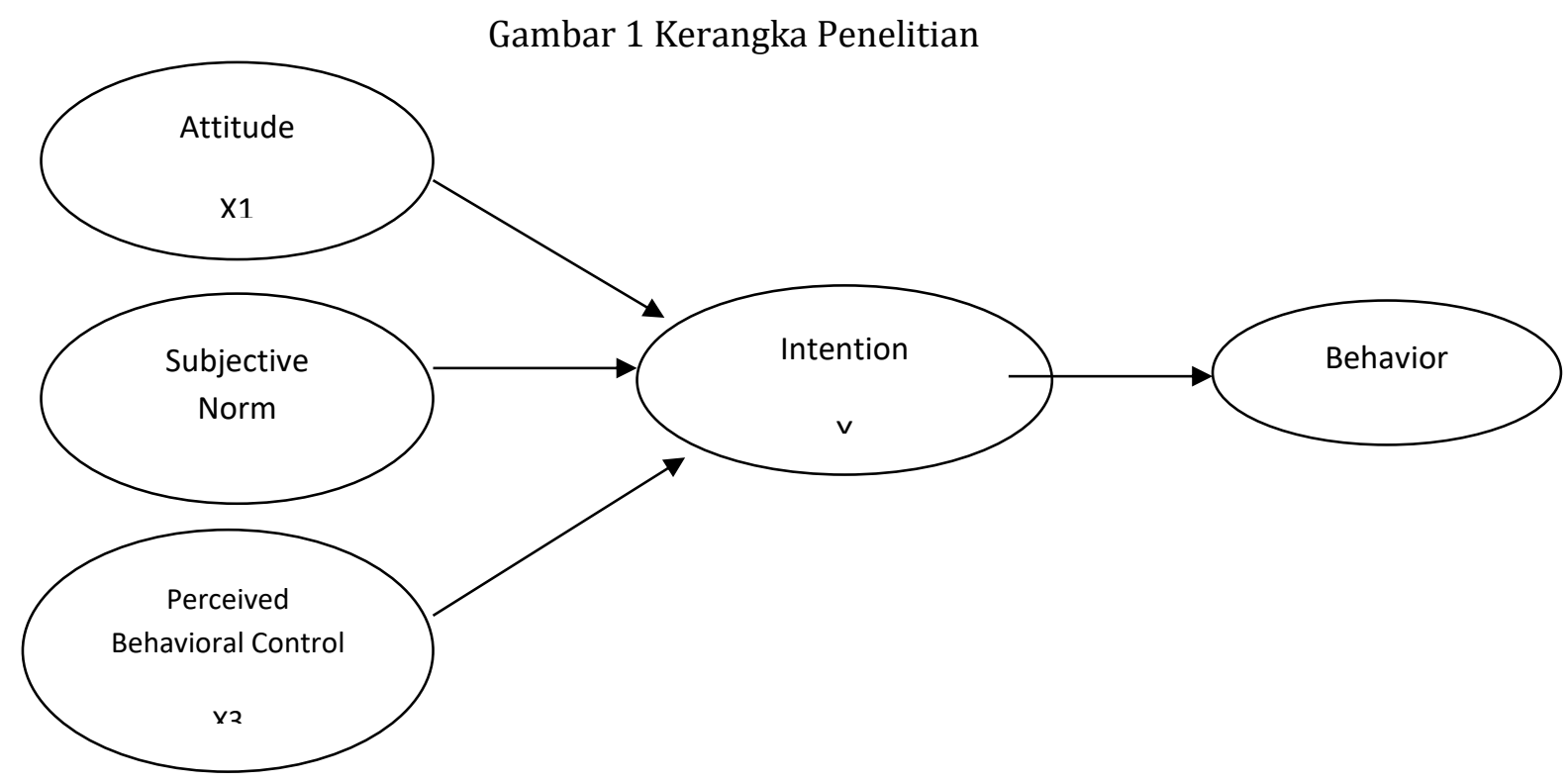

\section{HASIL DAN PEMBAHASAN}

Tabel 1

Multiple Regression Analysis

Coefficients $^{a}$

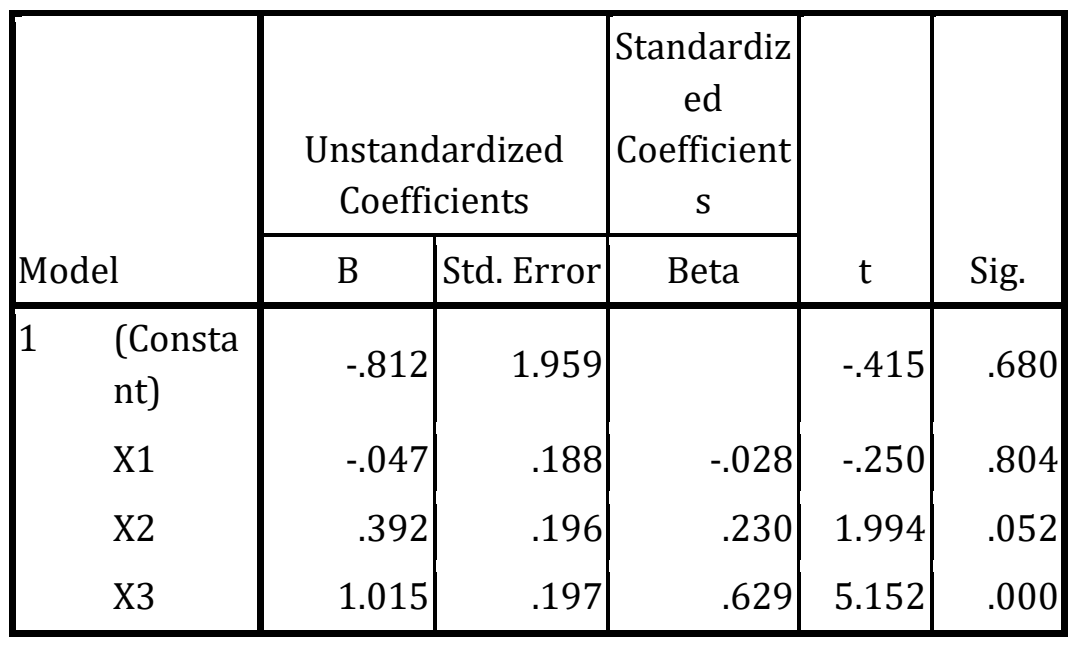




\section{Coefficients $^{\mathrm{a}}$}

\begin{tabular}{|c|c|c|c|c|c|}
\hline \multirow[b]{2}{*}{ Model } & \multicolumn{2}{|c|}{$\begin{array}{l}\text { Unstandardized } \\
\text { Coefficients }\end{array}$} & \multirow{2}{*}{\begin{tabular}{|c|}
$\begin{array}{c}\text { Standardiz } \\
\text { ed } \\
\text { Coefficient } \\
\text { s }\end{array}$ \\
Beta
\end{tabular}} & \multirow[b]{2}{*}{$\mathrm{t}$} & \multirow[b]{2}{*}{ Sig. } \\
\hline & B & Std. Error & & & \\
\hline $\begin{array}{ll}1 & \text { (Consta } \\
& \mathrm{nt})\end{array}$ & -.812 & 1.959 & & -.415 & .680 \\
\hline $\mathrm{X} 1$ & -.047 & .188 & -.028 & -.250 & .804 \\
\hline $\mathrm{X} 2$ & .392 & .196 & .230 & 1.994 & .052 \\
\hline X3 & 1.015 & .197 & .629 & 5.152 & .000 \\
\hline
\end{tabular}

$$
\mathrm{Y}=(-0.812)+(-0.047) \mathrm{X} 1+0.392 \mathrm{X} 2+1.015 \mathrm{X} 3
$$

Y : Intensi infaq dan shadaqah

$\mathrm{X} 1$ : Attitude

X2 : Subjective Norms

X3 : Perceived Behavioral Control

Tabel 2

Koefisien Determinan

Model Summaryb

\begin{tabular}{|c|c|c|c|c|}
\hline Model & R & R Square & $\begin{array}{c}\text { Adjusted R } \\
\text { Square }\end{array}$ & $\begin{array}{c}\text { Std. Error of } \\
\text { the Estimate }\end{array}$ \\
\hline 1 & $.765^{\mathrm{a}}$ & .585 & .557 & 2.14962 \\
\hline
\end{tabular}

Berdasarkan tabel di atas, koefisien determinan (R Square) dapat diartikan bahwa 58,5\% dari niat infaq dan shadaqah (Y) pada model regresi dapat dijelaskan oleh variabel independen Attitude (X1), Subjective norms (X2) dan Perceived behavior control (X3). Sedangkan ada 41,5\% dipengaruhi oleh variabel lain yang tidak digunakan dalam penelitian ini.

Tabel 3

F Test

ANOVA $^{b}$

\begin{tabular}{|l|c|c|c|c|c|}
\hline & $\begin{array}{c}\text { Sum of } \\
\text { Squares }\end{array}$ & $\mathrm{df}$ & Mean Square & $\mathrm{F}$ & Sig. \\
\hline
\end{tabular}




\begin{tabular}{|ll|r|r|r|r|r|}
\hline 1 & Regression & 299.060 & 3 & 99.687 & 21.573 & $.000 \mathrm{a}$ \\
& Residual & 212.560 & 46 & 4.621 & & \\
Total & 511.620 & 49 & & & \\
\hline
\end{tabular}

Berdasarkan tabel di atas, hasil F-hitung adalah 21.573 dengan nilai signifikansi 0,000<0,05. Ini menyimpulkan bahwa ada efek stimulan antara attitude, subjective norms, dan perceived behavior control terhadap niat infaq dan shadaqah menggunakan Go-Pay.

Tabel 4

T test

\section{Coefficients ${ }^{\mathrm{a}}$}

\begin{tabular}{|c|c|c|c|c|c|c|}
\hline \multirow{2}{*}{\multicolumn{2}{|c|}{ Model }} & \multicolumn{2}{|c|}{$\begin{array}{l}\text { Unstandardized } \\
\text { Coefficients }\end{array}$} & \multirow{2}{*}{\begin{tabular}{|c|}
$\begin{array}{c}\text { Standardized } \\
\text { Coefficients }\end{array}$ \\
Beta \\
\end{tabular}} & \multirow[b]{2}{*}{$\mathrm{t}$} & \multirow[b]{2}{*}{ Sig. } \\
\hline & & B & $\begin{array}{c}\text { Std. } \\
\text { Error }\end{array}$ & & & \\
\hline 1 & (Constant) & 1.524 & 1.207 & & $\begin{array}{r}1.26 \\
2\end{array}$ & .213 \\
\hline & $\mathrm{X} 1$ & .028 & .116 & .041 & .241 & .810 \\
\hline & $\mathrm{X} 2$ & .095 & .121 & .139 & .786 & .436 \\
\hline & X3 & 099 & .121 & 153 & 815 & 419 \\
\hline
\end{tabular}

Berdasarkan tabel di atas, hasil signifikansi dari variabel subjective norms dan perceived behavioral kontrol lebih kecil dari 0,05, yang berarti bahwa variabel dalam penelitian ini mempengaruhi secara parsial dan positif sedangkan variabel attitude lebih besar dari 0,05 yang berarti bahwa variabel attitude tidak berpngaruh secara parsial. Berdasarkan hasil ini, tingkat signifikansi variabel attitude mendapat 0,081 >0,05. Ini menyimpulkan bahwa attitude tidak berpengaruh secara positif dan signifikan. Secara umum, responden melihat bahwa infaq dan shadaqah tidak hanya bisa diberikan melalui Go-Pay, tetapi bisa melalui aplikasi financial teknologi yang lainnya, atau memberikan secara langsung kepada yang berhak menerima tanpa melalui perantara financial teknologi. Norma subyektif dalam penelitian ini diketahui memiliki pengaruh signifikan terhadap niat infaq dan shadaqah. Berdasarkan hasil tersebut, tingkat signifikansi norma subyektif mendapat skor 0,043<0,05. Ini menyimpulkan bahwa norma subyektif secara signifikan mempengaruhi niat infaq dan bershadaqah.. Secara umum, responden menjelaskan bahwa ada dorongan sosial terhadap responden untuk melakukan infaq dan bershadaqah menggunakan Go-Pay terutama dari keluarga. Perceived behavior control yang dirasakan juga mempengaruhi secara signifikan dan positif niat infaq dan shadaqah melalui Go-Pay. Berdasarkan hasil ini, tingkat signifikansi variabel perceived behavior control yang dirasakan mendapat 0,041<0,05. Ini 
menyimpulkan bahwa perceived behavior control yang dirasakan secara positif dan signifikan terhadap niat infaq dan shadaqah melalui Go-Pay.

\section{KESIMPULAN}

Berdasarkan hasil penelitian, pengguna Go-Pay mempunyai tingkat kesadaran yang tinggi untuk berinfaq maupun bershadaqah melalui Go-Pay. Pengaruh subjective norms dan perceived behavior control secara keseluruhan secara positif dan signifikan mempengaruhi niat pengguna Go-Pay untuk memberikan infaq dan shadaqah melalui Go-Pay sedangkan variabel attitude dalam penelitian ini tidak begitu berpengaruh. Hasil penelitian ini menunjukan bahwa theory of planned behavior mempunyai implikasi secara langsung terhadap perilaku individu untuk memberikan infaq dan shadaqah melalui Go-Pay. Semakin tinggi niat individu untuk memberikan infaq dan shadaqah melalui Go-Pay maka semakin besar pula kemungkinan perilaku tersebut akan terwujud. Hasil penelitian ini juga dapat digunakan sebagai masukan bagi BAZNAS dan Badan Amil Zakat lainnya untuk mengembangkan metode pembayaran zakat, infaq dan shadaqah melalui digital payment mengingat minat masyarakat dalam bertransaksi menggunakan digital payment semakin hari semakin meningkat.

\section{DAFTAR PUSTAKA}

Daulay, Abdul Hafiz dan Irsyad Lubis.. (2014). Analisis Faktor-faktor Penyebab Keengganan Masyarakat Membayar Zakat Melalui Instansi BAZIS/LAZ di Kota Medan. Jurnal Ekonomi dan Keuangan.

Fatimah. (2015). Religiosity on Shopping Orientation and Behavioral Intention for Moeslem Customer. Islamic Marketing Conferences.

Jogiyanto dan Abdillah, Willy. (2009). Konsep \& Aplikasi PLS (Partial least Square) Untuk penelitian Empiris. Yogyakarta: BPFE-Yogyakarta.

Mardany. (2017). An Analysis of Cash Waqf Participation Among Young Intelectual. Academic Conference, Istanbul.

Nasution, Irfan dan Andi Prayogi. (2015). The Utilization of Zakah Productive Towards MicroBusiness Growth and Mustahik Welfare. Jurnal. Universitas Muhammadiyah Sumatera Utara.

Novanto, Henry Reza., Muhammad Nafik H.R. (2014). Mengapa Masyarakat Memilih Menunaikan Zakat di Masjid Dibandingkan Dengan Lembaga Zakat?. JESTT

Osman, Faiz Amirul. (2014). An Analysis of Cash Waqf. Islamic Marketing Conferences.

Suliyanto. (2011). Ekonometrika Terapan : Teori dan Aplikasi dengan SPSS. Yogyakarta : ANDI

Suliyanto, W. Novandari, Sri Murni Setyawati. (2015). Persepsi Generasi Muda Terhadap Profesi Pengrajin Batik Tulis Di Purbalingga. Jurnal Ekonomi dan Bisnis Vol. XVIII No. 1. Universitas Jenderal Soedirman.

Uyun, Qurratul. (2015). Zakat Infaq Shadaqah dan Waqaf Sebagai Konfigurasi Filantropi Islam. Jurnal Islamuna.

Zikri, Sri Nirwana Sarowati., Mu'ady Yasin., Taufik Chaidir. (2017). Kemanfaatan Dana Zakat Bagi Mustahik. Jurnal Lembaga Keuangan dan Perbankan. 